\title{
KS. EUGENIUSZ HUGON EDWARD ANDERS (1874-1924) PROBOSZCZ I PIERWSZY DZIEKAN DEKANATU PIEKARSKIEGO
}

Biogramu ks. Andersa nie można znaleźć w żadnym polskim słowniku dotyczącym dziejów Górnego Śląska. To samo dotyczy biografistyki w języku niemieckim. Nazwisko ks. Eugeniusza Andersa w literaturze pojawia się sporadycznie $\mathrm{i}$ to głównie w związku $\mathrm{z}$ dziejami sanktuarium maryjnego w Piekarach $\mathrm{k}$. Bytomia!. Często natomiast pojawiało się na szpaltach czasopisma „Katolik Codzienny", drukowanego w Bytomiu i kolportowanego głównie w województwie śląskim i na Śląsku Opolskim. Równie często nazwisko ks. E. Andersa pojawiało się w „Dzienniku Śląskim”. Był to bowiem znany duchowny diecezji wrocławskiej, który mimo ciągle dokuczających mu chorób w latach 1913-1924 zdobył rozgłos i popularność, głównie jako odnowiciel kościoła pielgrzymkowego oraz kalwaryjskiego wraz z kilkudziesięcioma kaplicami na wzgórzu Cerekwica w Piekarach. Uznanie wiernych przyniosła mu także wydana w 1916 r. jego staraniem Ksiażka kalwaryjska służaca dla użtku patników kalwarie piekarskq zwiedzajacych z dodatkiem historii o cudownym obrazie Matki Boskiej oraz historii kościola $i$ kalwarii ${ }^{2}$. Jego nazwisko stało się jeszcze bardziej znane jako gospodarza i ,prezentera" sanktuarium maryjnego, przyjmującego wizyty dostojników kościelnych, władz wojewódzkich i państwowych.

Chociaż ośrodkiem pielgrzymkowym w Piekarach ks. E. Anders opiekował się zaledwie 11 lat, był to okres najtrudniejszy dla sanktuarium maryjnego w pierwszej połowie XX w. Złożyły się na to nie tylko I wojna światowa i następstwa traktatu wersalskiego, ale głównie skomplikowana sytuacja społecznopolityczna tej części Górnego Śląska, w wyniku której dochodziło do manifestacji, wielkich strajków, polaryzacji nastrojów patriotycznych po polskiej i niemieckiej stronie. Ekscesy i działania bojówek niemieckich zaowocowały trzema krwawymi powstaniami. Jednak pod naciskiem Komisji Międzysojuszniczej 25.06.1921 r. zawarto zawieszenie broni między powstańcami a Niemcami. Nie był to bynajmniej koniec wydarzeń znaczących dla społeczeństwa Górnego Śląska. Dopiero podpisanie przez Polskę i Niemcy 15.04. 1922 r. konwencji w Genewie w spra-

' Zob. Piekary. Pamiqtka koronacji cudownego obrazu Matki Boskiej Piekarskiej, która się odbyla dnia I5-go sierpnia 1925 roku, Piekary 1925, s. 143.

2 Archiwum Archidiecezji Katowickiej [dalej: AAK], Acta Furstbischoefl. Genera]Vicariat-Amts zu Breslau betreffend: Eugen Anders, Rep. A-45, Vol 1 
wie Górnego Śląska pozwoliło na wkroczenie 20 VI 1922 r. wojsk polskich do Katowic i przejmowanie $\mathrm{z}$ rąk władz alianckich terenów plebiscytowych przyznanych Polsce. Kilka miesięcy później (7 XI 1922 r.) papież Pius XI ustanowił Administrację Apostolską Śląska Polskiego, wydzielając z diecezji wrocławskiej obszar przyznany Polsce po podziale Śląska w 1921 r., który został podporządkowany bezpośrednio Stolicy Apostolskiej.

Nękany ciągłymi chorobami ks. Anders uczestniczył w tych wydarzeniach tylko sporadycznie. W tak uciażliwych warunkach przyszło mu bowiem realizować funkcje zarządzania sanktuarium. Czynił to jednak dzięki przymiotom charakteru, do których należy zaliczyć jego niesłychany upór, umiejętność sprawowania funkcji gospodarza, mimo gnębiącej go choroby, zręczne „wyręczanie się" sprawnymi współpracownikami, a nawet przygodnymi gośćmi - duchownymi w wielu obowiązkach proboszcza. Przełożeni i urzędnicy diecezjalni widzieli w nim wzór lojalności, stawiali go więc za przykład innym. Między innymi z tego właściwie względu został pierwszym formalnym dziekanem dekanatu piekarskiego, chociaż w praktyce także i w tej funkcji zastępowali go inni duchowni.

Eugeniusz Hugon Edward Anders urodził się 31 III 1874 r. we wsi Pawonków (Pawonkau) należącej do dóbr von Thaera, w powiecie lublinieckim, na Górnym Ślassku ${ }^{3}$. Jego ojciec, Oskar, był nauczycielem i miejscowym kierownikiem szkoły ludowej; pełnil także z ogromnym zangażowaniem funkcję organisty. Matka, Agnieszka z Pierschków, zajmowała się wychowywaniem dzieci i pracą na roli, która nigdy nie przynosiła zbyt dobrych plonów. Rodzinę łączyła codzienna modlitwa, częsty udział we Mszy św. oraz rozwijany duch poświęcenia i otwartości dla bliźnich. Po ukończeniu na Wielkanoc 1884 r. trzyklasowej szkoły w Pawonkowie Eugeniusz dzięki protekcji (ojca i proboszcza?) został przyjęty do cieszącego się znakomitą renomą Królewskiego i Katolickiego Gimnazjum św. Mateusza we Wrocławiu (Koenigliches katholisches St. Matthias-Gimnasium zu Breslau $)^{4}$. Decyzja ta wiązała się z koniecznością zaciaggnięcia przez rodziców pożyczek, ponieważ sytuacja materialna rodziny nie pozwalała na to, by opłacać czesne. Eugeniusz otrzymał świadectwo dojrzałości przed Wielkanocą $1893 \mathrm{r}$. Na Wydział Teologiczny Uniwersytetu Wroclawskiego został przyjęty 22 IV tr., a 25. VII tr. do Książęco-Biskupiego Konwiktu Teologicznego we Wrocławiu. W okresie studiów, które nie przychodziły mu łatwo, wstapił do Kółka Polskiego, które jak wiadomo - kształciło swych wychowanków w języku polskim. Był również członkiem zwyczajnym nielicznego Towarzystwa Akademików Ślązaków, które na zewnatrz zachowywało formę niemiecka, pod nazwą Wissenschaftlicher Verein Oberschlesischer Studenten, chociaż zajmowało się studiowaniem literatury pol-

${ }^{3}$ AAK, Curriculum vitae cand. Theol.Eugen Anders, Acta Fursbischoefl. General- Vicariat - Ants zu Breslau betreffend: Eugen Anders, Rep. A-45, k. 35.

${ }^{4}$ AAK, Zeugnis der Reise Anders Eugon Hugo Eduard, z dn. 07 III 1893, tamże, k. 10. 
skiej i historii Śląska ${ }^{5}$. Święcenia kapłańskie E. Anders przyjął 21 VI 1897 r. we Wrocławiu, z rak księcia kard. G. Koppa ${ }^{6}$. W sierpniu 1897 r. jako wikariusz został skierowany do rozległej parafii w Chełmie Wielkim (Gross Chelm), ${ }^{7}$ w dekanacie mikołowskim. Praca duszpasterska sprawiała mu wiele trudności z uwagi na konieczność nauczania religii w kilku ludnych osadach ${ }^{8}$ oraz celebrowania - chociaż nie w każdą niedzielę - Mszy św. w pięciu oddalonych o 2 do $6 \mathrm{~km}$ kaplicach. Z nie wyjaśnionych powodów już po roku pracy w Chełmie, po tym, jak 6 VIII 1898 r. otrzymał pismo od przebywajacego na urlopie w Johannisburgu księcia kard. G. Koppa, ks. Anders został przeniesiony na stanowisko II wikariusza do sanktuarium maryjnego w Piekarach. Odtąd razem z proboszczem ks. Leopoldem Nerlichem przyczynił się do budowy niepowtarzalnego klimatu sanktuarium przez kształtowanie kazaniami i nabożeństwami pobożności licznych grup pielgrzymów oraz wytrwała i owocną posługę konfesjonału, co dostrzegali nie tylko wierni, ale także proboszcz i dziekan'. Ten rodzaj pracy kapłańskiej bardzo odbiegał od modelu posługi w „Zwykłej” parafii i absorbowal ks. Andersa szczególnie od początku maja do końca października. W tym czasie ks. Anders był także moderatorem ,przydzielonych mu przez proboszcza” organizacji parafialnych, wśród których sam wyróżnial "Związek Parafialny pod Opieką Świętego Józefa”. Wynikało to - jak się wydaje - nie tylko z samej postawy członków organizacji otwartej na inicjatywy duszpasterskie moderatora; traktowano go bowiem jako „przywódcę”, zaufanego opiekuna duchowego, przed którym odczuwano respekt połączony z wielką życzliwością ${ }^{10}$. Nie należy wszakże zapominać o równie ważnym innym „wątku” posługi pastoralnej ks. Andersa. Otóż w tym okresie Piekary odgrywały szczególną rolę w polskim ruchu religijno- społecznym, kulturalnym i narodowym. Życie polskie zarówno tej miejscowości, jak i sasiednich ośrodków, pod wpływem Piekar przybierało wtedy bogate formy organizacyjne i pulsowało żywym tętnem. Do typowych należały organizacje skupiające zainteresowanych teatrem amatorskim, polskim śpiewem chóralnym, kółka czytelnicze i samopomocowe, bractwa rozwijające polską kulturę regionu. Inicjatorem tych poczynań był mieszkaniec Piekar Wawrzyniec Hajda, uosabiający wszystko to, co składało się na niepowtarzalność Górnego Śląska na przełomie XIX i XX w. ${ }^{11}$ Ten działacz

${ }^{5}$ E. Anders należał do Towarzystwa aż do chwili rozwiązania w 1899 r., a więc jeszcze dwa lata po przyjęciu święceń kapłańskich, co naturalnie wymagało płacenia składek członkowskich.

${ }^{6}$ Tuż po prymicjach ks. Anders musial poddać się leczeniu pracy serca i układu krążenia. Ta poważna dolegliwość dokuczała mu bardzo często przez całe życie.

${ }^{7}$ Obecna nazwa: Chełm Śląski.

${ }^{8}$ Były to: Kopciowice, Imielin, Zabrzeg Nowy Bieruń, Kosztowy, Bogtei - Chełm z Małym Chełmem, Blendów, Podłuże, Czarnuchowice, Giszowiec, Jamnice, wioski Jaz i Pasieczka.

${ }^{9}$ Opinia proboszcza ks. L. Nerlicha z dn. 23 IV 1900 r. i świadectwo dziekana z Radzionkowa ks. T. Kosmeli z dn. 16 IV 1900 r. podkreślają także inne pozytywne cechy charakteru ks. Andersa, takie jak łatwe nawiązywanie kontaktu $z$ wiernymi, dobra współpraca $z$ miejscowymi nauczycielami, harmonijne budowanie wspólnoty z kapłanami, umiejętność posługiwania się językiem polskim i niemieckim.

${ }^{10}$ Zob. wiersz anonimowego autora wygłoszony w czasie uroczystości organizacyjnej w sierpniu $1897 \mathrm{r}$.

${ }^{\prime \prime}$ Zob. J. W y c is 10 , Zasada pierwszeństwa odrodzenia religijno-moralnego przed narodowym, czyli dzialalność religijno spoleczna Wawrzynica Hajdy, [w:] J. W y c i s 1 o, $Z$ dziejów 
wychowujący młodzież w surowych zasadach ascetycznych i propolskich uczynił z Piekar - zdaniem starosty bytomskiego - „ein polnische Hochburg”. Wprawdzie na wszystkich etapach rozwoju chrześcijańskich ruchów społecznych odnajduje się ślady ludzi świeckich, którzy odczuwali wewnętrzną potrzebę dzielenia z przedstawicielami Kościoła hierarchicznego nowych problemów rodzących się na skutek przemian cywilizacyjnych, jednak działalność Hajdy w Piekarach miała wyjątkowy charakter. Wtopiony w Kościół, a zarazem tkwiący mocno w społeczeństwie ludzi ciężkiej pracy, był on zarówno nośnikiem nowej cywilizacji, bardziej godnej człowieka, jak i moralnych wymagań Ewangelii. Hajda zachęcał nieustannie do pracy nad sobą i oświecał, budując coraz mocniejszą sieć ludzkicj solidarności, która podsycała kruche związki między historią a wiarą. W ten sposób inicjował - szczególnie wśród młodzieży - zalążki nowych stosunków społecznych opartych na godności ludzkiej, majacych wykreować nową cywilizację cywilizację miłości. Zetknięcie się gorliwego, ale działającego w tradycyjnych ramach duszpasterskich ks. Andersa z ociemniałym gómikiem, a jednocześnie charyzmatycznym wychowawcą młodzieży w duchu religijno-narodowym niejednokrotnie musiało stwarzać między nimi napięcia. Wprawdzie obaj w swej posłudze zawsze preferowali godność człowieka osadzoną w Ewangelii, jednak trzeba przyznać, że Hajda nie tyle ukazywał, ile sam wyznaczał oryginalne drogi oraz metody służące realizacji wzniosłych celów opartych na Piśmie Świętym ${ }^{12}$.

Ciaggle pogarszający się stan zdrowia ks. E. Andersa, potwierdzony świadectwem zdrowia z dn. 21 VI 1900 r., wystawionym przez doświadczonego lekarza wojskowego pracującego równocześnie na stanowisku zaprzysiężonego lekarza knapszaftowego, w pobliskim Szarleju dr. D. Lorenza, stał się motywem prośby wikarego o przeniesienie na spokojniejsza placówkę duszpasterską ${ }^{13}$. Wikariat Generalny, przychylając się do prośby ks. Andersa, 3 VIII 1900 r. przeniósł go do Sakrau (Zakrzowa) koło Koźla, podkreślając w dołączonym piśmie adresowanym do proboszcza, iż nowy wikariusz, "nie dorósł” jeszcze do pełnienia funkcji w sanktuarium. Wprawdzie nowa placówka ks. Andersa, pod wezwaniem Sw. Mikołaja, posiadała cztery przysiółki ${ }^{14}$, ale jego obowiązki w niej ograniczały się do zwykłej posługi kapłańskiej. Dodatkowe utrudnienie stanowiły dojazdy do jednego z przysiółków - Stoeblau (Stebłowa), gdzie mieściła się jednoklasowa szkoła, do której uczęszczało sto dzieci. Jednak już 2 XI 1901 r. ks. Anders niespodziewanie został przeniesiony na stanowisko proboszcza w Eckerdorf (Biestrzykowi-

\footnotetext{
katolicyzmu spotecznego na Górnym Ślasku. W kręgu sanktuarium maryjnego w Piekarach Sla-

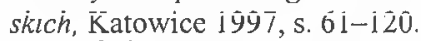

${ }^{12}$ Ślascy pisarze ludowi (1800-1914). Antologia poezji i prozy, oprac. J. Kucianka, Wrocław-Warszawa-Opole 1968, s. 182-183.

13 AAK, Świadectwo lekarskie Staabsarzta, a. D. Lorenza - Knappschaftarzt, Scharley O.S., Acta Furstbischoefl. General - Vicariat- Amts zu Breslau, betreffend: sygn. A-45, k. 62. W praktyce bowiem Generalny Wikariat we Wrocławiu nie był skłonny ,mechanicznie" udzielać dodatkowego urlopu (nawet zdrowotnego, przeznaczonego na kurację) duchownym z krótkim stażem duszpasterskim. Sytuacja ks. Andersa była jeszcze o tyle niekorzystna, że ciążyły na nim długi finansowe, które $z$ trudem spłacał ratami. Podjęcie ewentualnej kuracji wymagało także dysponowania odpowiednią kwotą pieniędzy, których oczywiście nie miał.

${ }^{14}$ Były to: Puhlau (Połowa zwana także Pustkami), Bitschnitz (Bycznica), Anheil Jaworowitz (Jaworowice) i Stoeblau (Stebłów).
} 
cach), w tzw. diasporze ${ }^{15}$. Chociaż nowa parafia wymagała od niego dużej sprawności fizycznej, ponieważ była bardzo rozległa - rozciagała się aż na dwa powiaty: Namslau (Namysłów) i Brieg (Brzeg), ks. Anders czuł się usatysfakcjonowa$n^{16}$. Samodzielne stanowisko rekompensowało mu utrudnienia w pracy duszpasterskiej. Z analizy materiałów archiwalnych wynika, że proboszcz często dzielił czas między gorliwym wypelnianiem obowiązków duszpasterskich a chorobą ${ }^{17}$. Zajęcia katechetyczne prowadził w trzech szkołach: Biestrzykowicach, Dammer (Dąbrowie) i Sbitze (Zbicy) ${ }^{18}$. Z uwagi na rolniczy charakter parafii frekwencja dzieci na lekcjach budziła duże zastrzeżenia, głównie w okresie prac polowych i miesiącach zimowych. Proboszcz w takich sytuacjach sam rezygnowal z dojazdów do szkoły. Nie miano mu tego za złe, gospodarze bowiem „oszczędzali” swoje zaprzęgi i czas. Po dwóch latach pracy w Biestrzykowicach ks. Anders częściej zapadał na zdrowiu ${ }^{19}$. Przynajmniej dwa razy w roku prosił Wikariat Generalny o dłuższy urlop zdrowotny. Do każdej prośby dołączał stosowne zalecenie opiekującego się nim lekarza. W czasie jego nieobecności w parafii zastępowali go duchowni z sąsiedztwa, szczególnie ks. prob. E. Warzecha z pobliskich Bankowitz (Bąkowic). Wówczas w dni powszednie w Biestrzykowicach nie było Mszy św., ponieważ binacje dozwolone były zasadniczo w niedziele i święta ${ }^{20}$.

\section{II}

Po dwunastu latach pracy w dekanacie namysłowskim ks. E. Anders kolejny już raz, zupełnie nieoczekiwanie, 18 XII 1913 r., został przeniesiony na stanowisko proboszcza sanktuarium maryjnego w Piekarach, gdzie przed laty był wika$\mathrm{rym}^{21}$. Do parafii przybył ,nie najlepiej usposobiony, gdyż dowiedział się, że piekarzanie zbierali podpisy za ks. Strzybnym, chcąc go koniecznie mieć proboszczem"22. Zmiana placówki duszpasterskiej musiała być dla niego sporym szokiem, głównie ze względu na stale pogarszający się stan zdrowia. Zatem, czym kierowali się duchowni urzędnicy diecezjalnej instytucji, jakim był Wikariat Generalny, oddelegowując ks. Andersa na bardzo odpowiedzialną, a jednocześnie eksponowaną placówkę, wymagająca, ,żelaznego" zdrowia i prawie szesnastogodzinnej dyspozycyjności każdego dnia.

${ }^{15}$ Oznaczało to, iż miejscowość zamieszkiwało więcej protestantów niż katolików.

${ }^{16}$ Należały do niej aż 23 kolonie (osady), z których Dammer-Oschiek (Osiek) była oddalona od kościoła o $14 \mathrm{~km}$. Zob. Handbuch des Bistums Breslau und seines Delegatur-Bezirks fur das Jahr 1907, Breslau (br.), s. 144.

${ }^{17}$ Po dwu latach posługi duszpasterskiej w tej miejscowości ks. Anders poprosił władze duchowne o urlop w celu przeprowadzenia „operacji zębów” i odprawienia rekolekcji w Naerishofen. Zob. korespondencja do Biskupiego Wikariatu Generalnego z 16 VI 1903 r.

${ }^{18}$ Inna nazwa: Granitz.

19 Zob. Korespondencja ks. E. Andersa do Książęco-Biskupiego Wikariatu Generalnego we Wrocławiu z 10 VII 1911 r., 27 VIII 1912 r. i nast. AAK, sygn. A-45, k. 82, 83, 84 a-b i nast.

${ }^{20}$ Tamże.

${ }^{21}$ Obowiązki w Piekarach przejął po zmarlym 13 IV 1912 r. ks. infułacie Pawle Zielonkowskim, który w sanktuarium pracował od 8 VIII1901 r.

22 „Dziennik Ślaski” 1913 nr 56. 
Do realizacji zadań duszpasterskich w Piekarach ks. Anders przystępował bardzo powoli, kontynuując dziela podjęte przez poprzedników i nawiązując do zastanych zwyczajów pastoralnych i społecznych. Początkowo gubil się w różnorodności działań, wysyłał bowiem bezzasadną koresponencję do Wikariatu Generalnego we Wrockawiu zawierająca wiele pytań o charakterze retorycznym. Najczęściej dotyczyły one możliwości tzw. binacji dni powszednie ${ }^{23}$, udzielania sakramentu chorych w ich mieszkaniu oraz celebrowania Mszy św. w kaplicy ${ }^{24}$. Pytał także o to, czy Mszę św. w intencji parafian może w zastępstwie proboszcza celebrować wyznaczony wikariusz ${ }^{25}$. Nie potrafił także sam podjać decyzji, czy wikariusz może udawać się do chorego zaprzęgiem konnym, za który przecież należy zapłacici ${ }^{26}$. Do co najmniej dziwnych zachowań proboszcza piekarskiego należy także zaliczyć korespondencję skierowaną do biskupa z prośbą o ukaranie działacza społecznego R. Kornkego, który „odważył się” przemawiać nad grobem zastrzelonego policjanta, bez zezwolenia proboszcza ${ }^{27}$. Takie postępowanie charakteryzowało go aż do śmierci ${ }^{28}$. Skrupuly bezpowrotnie opuszczały proboszcza w chwili pisania prośby o urlop zdrowotny, na co zawsze miał tzw. podkładkę ${ }^{29}$.

Pierwszą większą i dobrze przemyślaną inicjatywą duszpasterską w Piekarach było zorganizowanie $w$ dn. od 30 XI 1913 r. do 4 I 1914 r. misji parafialnych prowadzonych przez księży misjonarzy ze zgromadzenia sw. Wincentego a Paulo z Krakowa ${ }^{30}$. Do Piekar przybyła wyznaczona grupa misjonarzy, którzy głosili nauki rano i wieczorem, odprawiali nabożeństwa dla różnych stanów przy wystawionym Najświętszym Sakramencie, w sposób atrakcyjny i czynny wdrażali starsze dzieci szkolne i młodzież w nauczanie katechetyczne ${ }^{31}$. Sporo uwagi i czasu misjonarze przeznaczali na wspólne modlitwy i śpiewy, których celem było

${ }^{23}$ Np. Korespondencja ks. Andersa z kard. G. Koppem z 6 I 1914 r.

${ }^{24}$ Zob. Korespondencja z kard. G. Koppem z 24 VI 1913 r.

${ }^{25}$ Pismo ks. Andersa do Wikariatu Generalngo z 22 IX 1913 r.

${ }^{26}$ Zob. Korespondencja ks. E. Andersa do Administratora Apostolskiego w Katowicach A. Hlonda z 28 II 1923 r. Koszty wynajacia zaprzęgu konnego obliczył na 30 tys. marek niemieckich; Korespondencja ks. Andersa z 17 III 1923 r. Zob. AAK, Akten der Furstbischoeflichen Geheimen Kanzlei zu Breslau betreffend Deutsch Piekar, Archipresbiterat Tarnowitz, B. 2, Angelegt 1910, geschlosen 1930, Sect. II, Lit D, Nr 28; k. 52-53; k. 84; Korespondencja ks. Andersa $z 17$ III $1923 \mathrm{r}$.

${ }^{27}$ Ks. Anders złożył najpierw „wniosek karny” przeciwko R. Kornkemu u prokuratora w Izbie Karnej w Tarnowskich Górach, która go natychmiast odrzucila „z braku cech przestępstwa". Tamże, k. 55-57.

${ }^{28}$ Odpowiedzi Książęco-Biskupiego Wikariatu Generalnego na pytania, prośby i wątpli-

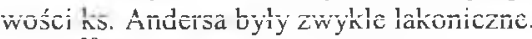

${ }^{29}$ Często ks. Anders prosił w kolejnej korespondencji do Wikariatu Generalnego o zwrot świadectwa lekarskiego, które było mu potrzebne w dalszej kuracji.

${ }^{30}$ Pisemna prośba ks. Andersa do kard. Koppa z 23 X 1913 r. W korespondencji prosił nie tylko o możliwość zorganizowania misji, ale głównie podkreślał, że ostatnia tego typu akcja duszpasterska była przeprowadzana w parafii w czerwcu 1896 r. z okazji poświęcenia miejscowej kalwarii przez kard. M. de Diepenbrocka. Ks. Anders zaprosił w celu głoszenia misji jezuitów, ale nie otrzymali oni pozwolenia władz niemieckich obawiających się ,podkopania fundamentow państwa, a może i rozwielmożnionego hakatyzmu". Najwięcej obaw władz administracji niemieckiej wzbudzały nauki misyjne głoszone przez jezuitę ks. Asmanna. Zob. „Dziennik Śląski" 1914 nr 1.

${ }^{31}$ Tamże. 
utrwalanie prawd wiary ${ }^{32}$. Warto zaznaczyć, że w tych ćwiczeniach duchowych osobne nabożeństwa przeznaczone były także dla Niemców mieszkających w samych Piekarach i w sąsiednich miastach - Bytomiu i Tarnowskich Górach ${ }^{33}$. Jak zawsze w czasie misji, nie zawiodła wiejska okoliczna ludność, która utartym zwyczajem skoro świt przybywała do sanaktuarium. Wielu korzystało z posługi konfesjonału, która pełnili nie tylko misjonarze i miejscowi duchowni, ale także duszpasterze z sąsiedztwa. Akcją udzielania sakramentu pokuty koordynował ks. Anders, który mimo nękającej go choroby starał się czynnie włączać w prace duszpasterskie zabezpieczające pomyślny i sprawny przebieg misji ludowych. Wielkie misje piekarski proboszcz przeprowadził, mimo sprzeciwu władz rejencji opolskiej, które wszelkimi sposobami nie chciały do nich dopuścić, obawiając się wzrostu polskich dazzeń w Piekarach. Ks. Anders miał jednak dość cywilnej odwagi i uporu, by sprzeciwić się naciskom osławionego krzewiciela germanizacji w szkołach (erster Dirigent der Schulabteilung) R. Kustera, który będąc kierownikiem Wydziału Szkolnego Administracji Opolskiej (Abteilung für Kirchen und Schulwesen) specjalnie przybył do Piekar, by zmusić nowo mianowanego proboszcza, aby zaniechał swego zamiaru. R. Kiister był przekonany, że ks. Anders syn kierownika szkoly wychowany przecież $w$ duchu niemieckim, zrezygnuje z przeprowadzenia misji przez księży Polaków; pomylił się jednak. Misje zakończyły się poświęceniem krzyża na tzw. Rajskim Placu, a ta uroczystość zgromadziła olbrzymią rzeszę wiernych (nawet Niemców) z „bliższych i dalszych stron”. Dzięki swojej postawie i inicjatywnie duszpasterskiej w Piekarach ks. Anders zdobył pewną popularność, stał się bardziej znany w środowisku ludzi ciężkiej pracy zatrudnionych $\mathrm{w}$ przemyśle górnośląskim, a tym samym zwrócił uwagę spoleczeństwa na rolę i znaczenie Piekar w życiu Polaków.

Dostrzegając pewne ożywienie religijne, zwiększył liczbę celebrowanych Mszy św. oraz nabożeństw w kościele pielgrzymkowym [i kalwaryjskim?], co spotkało się z wdzięcznością wiernych. Słuszną decyzję proboszcza piekarskiego potwierdziła m.in. frekwencja wiernych w czasie uroczystości odpustowej (Nawiedzenie Najświętszej Maryi Panny) w dn. 5 i 6 VII 1914 r., ,która ściagnęła tysięczne zastępy $\mathrm{z}$ wszystkich stron kraju" ${ }^{34}$. Na tej samej fali ożywienia religijnego ks. Anders założył Kongregację Mariańską ${ }^{35}$ dla młodzieńców, sprzeciwiając się decyzji wrocławskiego biskupa, by przyłączyć ją do analogicznych organizacji niemieckich, za pozwoleniem wrocławskich władz duchownych reaktywował Towarzystwo św. Alojzego, później zorganizował (1921 r.) Apostolstwo Męźów Katolickich, zaktywizował chór kościelny oraz kilka bractw o charakterze społeczno-religijnym i formacyjnym, m. in.: Straż Honorową Najświętszego Sakramentu $^{36}$, Związek św. Józefa ${ }^{37}$ i Bractwo Wstrzemięźliwości ${ }^{38}$. Na posiedzeniach religijnych organizacji parafialnych przemawiał zawsze w języku polskim.

${ }^{32}$ A. R o th e, Volksmissionen vor 100 Jahren in Ost- und Westpreussen, „Mitteilungen aus den deutschen Provinzen" 1960-1962, 19, s. 9-12; T e n ż e, Schlesische Jesuiten aus den 19. Jahrhundert, „Archiv fur Schlesische Kirchengeschichte“ 1960, t. 18, s. 217-271.

${ }^{33}$ "Katolik" $1914 \mathrm{nr} 2$.

${ }^{34}$ "Dziennik Śląski" 1914 nr 156.

${ }^{35}$ Zob. korespondencja ks. Andersa do kard. G. Koppa z 4 III 1916 r. Funkcjonowała ona w Piekarach już od lipca 1848 r. Po kilkudziesięciu latach widocznie zaprzestala działalności.

${ }^{36}$ Założył ją w $1911 \mathrm{r}$. ks. infułat P. Zielonkowski

37 „Katolik” 1914 nr 77. 
Ośrodek pielgrzymkowy z kościołem wybudowanym przez ks. Ficka w Piekarach cieszył się więc nadal dobrą renomą religijno-społeczną ${ }^{39}$. Dobrodziejstwa Matki Bożej Piekarskiej utrwalano - jednak już bez osobistego zaangażowania ks. Andersa - w tradycji kulturowej Górnego Śląska w kazaniach i artykułach ukazujących się w lokalnej prasie religijnej, a najczęściej przez sprzedaż pielgrzymom bloczków z barwnymi bądź dwukolorowymi kartami pocztowymi ${ }^{40}$. Zamierzając odnowić wymagającą nieustannego remontu i doglądania bazę materialną parafii, szczególnie zaś kaplic kalwaryjskich ${ }^{41}$ oraz terenu przykościelnego wraz z kościolem pielgrzymkowym ${ }^{42}$, ks. Anders wynajał obszar pola uprawnego parafianom. Naturalnie, otrzymał na to zgodę Wikariatu Generalnego we Wrocławiu. Jednak ze względu na dewaluację marki niemieckiej decyzja ta nie przyniosła spodziewanego dochodu.

Mimo niespokojnej sytuacji międzynarodowej ks. Anders zdecydował się na podjęcie prac renowacyjnych zarówno w kościele pielgrzymkowym, jak i w krużgankach na placu przykościelnym oraz na wzgórzu kalwaryjskim ${ }^{43}$. Była to odważna decyzja, ponieważ wymagała znacznych nakładów finansowych, a społeczeństwo - głównie polskie - nie należało do bogatych. Poza tym front robót zapowiedziany przez proboszcza był bardzo rozległy: wymagal zatrudnienia wielu fachowców, głównie z dziedziny budownictwa (murarzy, tynkarzy, malarzy, kowali), a także co najmniej kilkunastu pomocników. Jednak wbrew obawom roboty można było rozpocząc wiosną $1914 \mathrm{r}$., a chętnych do pracy nie brakowało ${ }^{44}$. Już na początku lata w prasie polskiej napisano, iż „Po latach zaniedbania - wszędzie panował wzorowy porządek, chociaż prace malarskie i tynkarskie na Rajskim Placu nie były jeszcze zakończone" ${ }^{\text {"45 }}$. Większego remontu wymagał kościół kalwaryjski i kaplice kalwaryjskie ${ }^{46}$, ale i ten problem ks. Anders zdołał rozwiązać $\mathrm{w}$ ciagu roku ${ }^{47} . \mathrm{Z}$ tego powodu popularność piekarskiego proboszcza z pewnością wzrosła nie tylko w środowisku kapłańskim, ale głównie wśród pielgrzymów.

Jeszcze większe zaskoczenie ludzi wierzących, zarówno Polaków, jak i Niemców, wywołała nieoczekiwana, ale przemyślana przez proboszcza decyzja o podjęciu przez niego starań o koronację obrazu Matki Bożej słynącego cuda-

${ }^{38}$ Ks. Anders nie potrafił ustalić daty założenia tego bractwa. W korespondencji do władz duchownych podawał datę ,29 VII 1851, wzgl. 1 IX 1851”. Obie były nieprawdziwe, ponieważ ks. Ficek założył je już w sierpniu 1844 r.

${ }^{39}$ Wynika to głównie z analizy treści „Dziennika Śląskiego", który od 1923 r. zmienił tytuł na „Katolik Codzienny”, „Katolika”, „Katolika Śląskiego” i „Katolika Polskiego”. Zob. np. „Dziennik Śląski” $1914 \mathrm{ntr} 156$.

${ }^{40} \mathrm{Na}$ potrzeby zawsze chłonnego rynku dewocjonalii i pamiątek wytwarzali je: Zakład

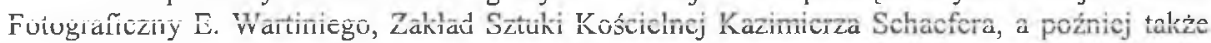
Zakład Fotograficzny Eryka Zosgórnika z Piekar, współpracujący z drukarnią „Papyrus” z Tarnowskich Gór.

41 „Dziennik Śląski” 1917 nr 202. Pracami renowacyjnymi kaplic kalwaryjskich kierował artysta malarz Siemon $z$ Nysy.

${ }^{42}$ „Dziennik Śląski” 1914 nr 145, 164.

43 "Dziennik Śląski" 1914 nr 156, 164.

${ }^{44}$ Koszty remontu samego kościola obliczono na 20 tys. marek niemieckich. 2/3 kosztów pokrywał patron, czyli rejencja opolska. Zob. „Katolik” $1915 \mathrm{nr} 46$.

45 „Dziennik Śląski” 1914 nr 145

${ }^{46}$ Por. „Dziennik Śląski” 1915 nr 119, 148.

${ }^{47}$ „Dziennik Śląski” 1915 nr 86, 119. 
$\mathrm{mi}^{48}$. Nie była to wszakże oryginalna myśl ks. E. Andersa, lecz kontynuacja idei z roku 1683, autorstwa ówczesnych opiekunów kościoła z obrazem Matki Bożej w Piekarach - jezuitów ${ }^{49}$. Ksiądz Anders ogłosił swoje zamiary koronacji obrazu podczas wielkiego odpustu Nawiedzenia Matki Bożej, w dn. 4 i 5 VII 1914 r., który tradycyjnie gromadził wielką rzeszę pielgrzymów ${ }^{50}$.

Gdy pod koniec lipca 1914 r. prusko-niemieckie władze administracyjne zainscenizowały na Górnym Śląsku sztuczny „entuzjazm wojenny”, a jednocześnie w obawie przed demonstracjami niezadowolonej ludności polskiej podjęły prewencyjne kroki takie jak: rewizje, aresztowania, zawieszenie wydawania prasy polskiej, czemu dodatkowo towarzyszył terror oraz podejrzliwość ${ }^{51}$, do sanktuarium zaczęło przybywać więcej ludzi młodych - potencjalnych poborowych $i$ ich rodziny. $\mathrm{Z}$ tego względu ks. Anders więcej czasu musiał przeznaczać na konfesjonat $^{52}$. Przychodziło mu to $z$ trudnościa, ponieważ ciagle chorował.

Zaledwie po roku pracy ks. Andersa w Piekarach na probostwie zostało zakwaterowane wojsko niemieckie ,wraz z baterią armat stojącą w obejściu i ogrodzie". W duchu pokory i „niezbadanych wyroków Boskich” ks. Anders musiał godzić się z faktem, iż „nie jest panem probostwa" ${ }^{53}$. Teraz także, jakby częściej, zaczęły się na to składać przekazywane z pokolenia na pokolenie informacje dotyczące wysłuchiwania przez Matkę Bożą Piekarska próśb zanoszonych przed Jej cudami słynącym obrazem.Na pewno wynikało to $z$ niepokoju związanego $z$ sytuacją międzynarodową, a zatem z groźbą wybuchu wojny.

Tymezasem wzmagała się propaganda wojenna, zapewniająca zbałamuconą ludność o szybkim i zwycięskim zakończeniu działań wojennych ${ }^{54}$. W Piekarach, jak w każdej przygranicznej miejscowości, mówiło się o mającej rzekomo nastapić ofensywie wojsk rosyjskich na Górny Śląsk. Zaobserwowane przez mieszkańców nadgranicznych miejscowości położonych w sąsiedztwie Piekar przygotowania Rosjan do ofensywy zdawały się potwierdzać najbardziej pesymistyczne nastroje. Żołnierze rosyjscy bowiem pomiędzy Czeladzia a Sosnowcem zgromadzili 100 cetnarów dynamitu, aby przed ofensywą na Górny Śląsk (właśnie w Piekarach) wysadzić budynki przeszkadzające piechocie i kozakom w natarciu ${ }^{55}$. Wiadomość ta budziła grozę. $Z$ tego powodu wielu czcicieli Maryi, znając barbarzyństwo Rosjan, a szczególnie kozaków, obawiało się nie tylko o własne życie, ale także o przyszłe losy kościoła pielgrzymkowego w Piekarach i kopii cudownego

48 „Dziennik Śląski” 1914 nr 156; 1918 nr 108, 112, 120; 1921 nr 134.

${ }^{49}$ Zob. E. S z r a m e k, Koronacja obrazu Matki Boskiej w Piekarach dnia 15 -go sierpnia 1925 r., [w:] Piekary. Pamiqtka koronacji cudownego obrazu Matki Boskiej Piekarskiej, która się odbyta 15-go sierpnia 1925 roku, Piekary 1926, s. 119.

so "Katolik" 1914, nr 84.

${ }^{51}$ Dzieje Górnego Ślaska w latach 1816-1947, red. F. Hawranek, Opole 1981, s. 254 n.; M. L i s, Górny Slqask. Zarys dziejów do polowy XX wieku, Opole 2001, s. 127.

52 AAK, Acta Furstbischoefl. General-Vikariat-Amts zu Breslau betreffend: Eugen Anders, sygn. A-45, Vol. 1, k. 82 .

${ }^{53}$ Tamże, k. 83 a.

${ }^{54}$ M. C z a pli ńs ki, E. K a s z u b a, G. W ąs, R. Że r l i k, Historia Ślquska, Wrocław 202, s. 342 .

${ }_{55}$ Informacja napisana na karcie pocztowej nr 10 pt. Matka Boska jako obrona, wydanej przez E. Wartiniego z Niemieckich Piekar w roku 1914. 
obrazu Matki Bożej ${ }^{56}$. Zatem nieustannie bacznie obserwowano zachowanie się rosyjskiej straży granicznej pełnionej przez kozaków. Lokatorzy budynków kopalnianych w pobliżu szybu „Rozalia”, z którego zaopatrywali się w wodę, nawiązali w tym celu niezbyt legalne kontakty z żołnierzami rosyjskimi. Według nich w dniu wybuchu I wojny europejskiej, która później stała się światową tj. 2 VIII 1914 r., rosyjscy zwiadowcy powiadomili swoich dowódców o niesłychanie wzmożonym ruchu osobowym zmierzającym do Piekar. Oficerowie dopatrywali się w tym fakcie niespodziewanej koncentracji wojsk autro-węgierskich, dlatego też zaniechano natarcia na tym odcinku frontu, ponieważ nie dysponowano odpowiednio silnymi oddziałami ${ }^{57}$. Tymczasem nie chodziło o żadne przegrupowanie lub koncentrację wojska pruskiego, ale o tłumy pielgrzymów, które furmankami, rowerami, względnie pieszo w zorganizowanych grupach zdążaly na uroczystość Najświętszej Maryi Panny Anielskiej w celu uzyskania tzw. odpustu Porcjunkuli ${ }^{58}$ właśnie w dn. 2 VIII 1914 r. Dla wielu Polaków i katolików mieszkających na Górnym Śląsku wyjaśnienie tego zdarzenia było proste i nie budziło wątpliwości. To Matka Boża Piekarska z „niewidzialna armia" ocaliła „swoje” sanktuarium wraz z miejscowością i okolicą. Przybyła na pomoc wiemym czcicielom i w najniebezpieczniejszej dla nich chwili powstrzymała nieprzyjaciół przed zdewastowaniem głównego ośrodka ruchu pielgrzymkowego ${ }^{59}$. Dlatego od tego dnia do zakończenia II wojny światowej nazywano ją Matką Bożą Piekarską Obrończynią [Ludu Górnoślasskiego]. Wieść bowiem o „cudownym” ocaleniu Piekar, ziemi bytomskiej i Górnego Śląska za przyczyną Matki Bożej Piekarskiej rozeszła się po całym regionie ${ }^{60}$. „Cudowne" ocalenie Piekar wielokrotnie opisywała potem katolicka prasa lokalna ${ }^{61}$. W rzeczywistości ofensywa rosyjska na Śląsk została zaniechana, a zimą 1914 r. ustalił się front i rozpoczęła wojna pozycyjna.

Popularność ks. Andersa jako kustosza sanktuarium maryjnego w Piekarach po tym zdarzeniu po raz kolejny wzrosła, gdyż w szczęśliwie zakończonym epizodzie wojennym upatrywano potwierdzenia ,przez niebo" słusznej decyzji proboszcza o ukoronowaniu obrazu Matki Bożej Piekarskiej.

Ponieważ działania wojenne, sytuacja na rynku i w zakładach pracy nie skłaniały wiernych do optymizmu, do sanktuarium nie przybywały już takie tłumy, jak do tej pory. Proboszcz mógł zatem więcej czasu przeznaczyć na leczenie. Nie mógł jednak korzystać z kuracji w znanych kurortach. Leczył się więc na miejscu - na probostwie, w swym pokoju, z którego czasem nie wychodził bez potrzeby nawet przez kilka dni. Doszło nawet do tego, że z powodu wielkiej drożyzny mieszkańcom probostwa zaczął doskwierać niedostatek. Z czasem nie opuszczaja-

${ }^{56}$ Oryginał obrazu w obawie nrzed wnjskami s7wedzkimi Karola XII jezunici snrawụiaçy wówczas duszpasterstwo w Piekarach w tajemnicy 20 VII 1702 r. wywieźli do Opola, skąd do Piekar już nie wrócił.

57 „Piekarskie Wiadomości Parafialne” 1931 nr 32.

s8 "Piekarskie Wiadomości Parafialne" $1932 \mathrm{nr} 31$.

${ }^{59}$ Muzeum w Chorzowie, sygn. MCH F, nr 2052. Eksponat udostępniła p. mgr Zofia Brachaczek.

${ }^{60}$ Nie potwierdza tego były mieszkaniec Piekar Alfred Georg Seidel, autor wspomnień pt. Himmel uber Grenzen, Reutingen 1998; wyd. polskie: Przygraniczne Niebo[!], Gliwice 2001.

${ }^{61}$ Wydano nawet specjalną kolorową pocztówkę upamiętniająca to wydarzenie. Czarno-biało-zieloną wersję tej widokówki zamieszczono w okolicznościowym albumie wśród innych 11 fotografii. Album ten sprzedawano w latach międzywojennych jako „wizytówkę" Piekar. 
ce go choroby, nadmiar pracy i niedostatek sprawiły, iż ks. Anders stał się bardzo drażliwy ${ }^{62}$. Potrafił się jednak mobilizować, gdy zachodziła ku temu potrzeba, np. w chwili przybycia do sanktuarium ważnego gościa lub grupy pielgrzymów znaczących w życiu społecznopolitycznym. Uważał wówczas, iż do jego obowiązków pastoralnych należy dotrzymywanie im towarzystwa i udzielanie niezbędnych informacji. Przykładów tego rodzaju można by przytoczyć więcej, chociażby wizyta metropolity abp. Simona w dniu 14 IX 1914 r., czy biskupa pomocniczego z Wrocławia ks. Karola Augustyna udzielającego sakramentu bierzmowania 6 X 1915 r. grupie nie tylko młodych parafian ${ }^{63}$, którego proboszcz powitał także $\mathrm{w}$ imieniu 2000 Polaków z parafii zaciagniętych do wojska pruskiego ${ }^{64}$ (w ramach restrykcyjnej polityki zmierzającej do wykrwawienia ludności polskiej) ${ }^{65}$. Gdy tydzień poźniej z wizytą do Piekar przybył z Wrocławia książę biskup A. Bertram ${ }^{66}$, ks. Anders mimo choroby przywitał go w sanktuarium w języku polskim i niemieckim, prosząc jednocześnie o pasterską opiekę nad tym miejscem pielgrzymkowym $^{67}$. Od 1916 r., mimo trwających działań wojennych, zaczął częściej korzystać $\mathrm{z}$ możliwości leczenia w znanych kurortach. Zwyczajowo były to Karlove Vary i Kudowa. W czasie nieobecności proboszcza praca duszpasterska spoczywała na wikarych bądź na duchownych przebywających w parafii u rodziny na okolicznościowych urlopach. Ks. Anders potrafił te okazje doskonale wykorzystywać, gdy bowiem przybywał do wymienionych kurortów na leczenie, natychmiast prosił miejscowego lekarza głównego o zaświadczenie stwierdzające konieczność przedłużenia jego kuracji 68 .

W krótkich okresach między leczeniem proboszcz był bardziej widoczny w pracy duszpasterskiej. Wygłaszał dla członków parafialnych organizacji prelekcje religijno-moralne i religijno-kulturalne. Akceptował organizowanie przez nie pielgrzymek na Górę św. Anny. Popierał też urządzanie wieczorów kolędowych, które m.in. podtrzymywały tradycję miejscowej ludności do śpiewania. Chętnie udzielał zezwolenia liderom tych organizacji na zaproszenie do parafii polskich organizacji religijno-spolecznych i kulturalnych, np. z Rozbarku, dzisiejszej dzielnicy Bytomia, lub ze Świętochłowic. Dopuszczał do wystawiania przez katolickie organizacje amatorskich przedstawień teatralnych, z których dochód często bywał przeznaczany na remonty piekarskich obiektów sakralnych.

${ }^{62}$ AAK, Akten der Furstbischoelfichen Geheimen Kanzlei zu Breslau betreffend Deutsch Piekar, Archipresbiterat Tarnowitz, B. 1, Angelegt 1910, Rep. A-45, Vol 1, k. 69.

${ }_{63}$ „Dziennik Śląski” 1915 nr 223, 227, 232; „Katolik” 1915 nr 119; nr 121. Zob. też. „Katolik' $1918 \mathrm{nr} 117$.

${ }^{64}$ „Dziennik Śląski” 1915 nr 232, 21 II 1915 r. poległ pochodzący z Piekar m.in. student teologii Ignacy Gola „ugodzony granatem w pierś w walce pod Ripont w okolicy Reims”. Zob. „Dzienik Ślaski” 1915 nr 63.

${ }^{65}$ W ramach tej mobilizacji zaciagnięto do wojska aż 25\% górników śląskich (w niemieckich zagłębiach Saary i Ruhry tylko 5-6\%).

66 „Dziennik Śląki” 1915 nr 237. W czasie krótkiej wizytacji bp. Bertram spotkał się także z landratem dr. Trappenbergem, sołtysem dr. Schindlerem, z niemieckimi nauczycielami i członkami stowarzyszeń religijnych oraz społecznokulturalnych.

${ }^{67}$ Tamże.

${ }^{68}$ Zarówno w Karlowych Varach dr Drieschel, jak i w Kudowie prof. Erklautz znali dolegliwości ks. Andersa i wystawiali mu odpowiednie świadectwa zdrowia. Pozwalało to czasem piekarskiemu proboszczowi trzykrotnie przedłużać urlop zdrowotny, mimo wyraźnej niechęci urzędników Wikariatu Generalnego. 
Po krótkim okresie znacznej aktywności pastoralnej proboszcza piekarskiego następował nawrót dolegliwości chorobowych. Ks. Anders zmuszony bywał zatem do kierowania odpowiedniej prośby do Generalnego Wikariatu we Wrocławiu. Władze zwierzchnie tylko raz „z entuzjazmem" przychyliły się do jego życzeń. Wniosek taki można wysnuć z korespondencji ks. Andersa w zwiazku z opublikowaniem przez niego w II kwartale 1917 r. tzw. piekarskiej książki kalwaryjskiej, tj. książi modlitewnej pomagającej wiernym w modlitwach i rozmyślaniach podczas nabożeństw Drogi Krzyżowej na kalwarii w Piekarach. Dotychczas wierni korzystali z obszernego modlitewnika kalwaryjskiego wydanego w 1897 r. przez jednego z proboszczów w Piekarach - ks. Leopolda Nerlicha ${ }^{69}$. Ks. Anders, wydając „swój” modlitewnik, kierowal się więc sprawdzonym wzorem lokalngo modlitewnika. Musiał go jednak zmodyfikować, przystosowując do innych warunków czasowych. Zasadniczą innowację modlitwnika zapowiadał sam jego tytuł: Ksiqżka kalwaryjska służ̨ca dla użytku pąników kalwarię piekarska zwiedzajacych $z$ dodatkiem historii o cudownym obrazie Matki Boskiej oraz historii kościoła $i$ kalwarii. Liczący 5 stron dodatek zawierał nadto spis wszystkich aktualnych odpustów w sanktuarium w Piekarach (8) oraz Napomnienia przy rozpoczęciu drogi krzyżowej ${ }^{70}$. Dochód $\mathrm{z}$ tej inicjatywy edytorskiej ks. Anders w całości przeznaczył na renowację kaplic i kościoła kalwaryjskiego, uzupełnienie egzotycznej zieleni oraz częściowo zrujnowanych murów otaczających Wzgórze ${ }^{1}$. Do kupna modlitewnika zachęcano nie tylko w ogłoszeniach parafialnych i po kazanach odpustowych, ale także w regionalnej prasie, np. w „Dzienniku Ślaskim” i „Katoliku”, Tak więc sukces edytorski i popularność „kalwaryjki” ks. Andersa, zapewniająca sukces ekonomiczny, nastawiły przychylnie urzędników Wikariatu Generalnego we Wrocławiu do udzielenia proboszczowi piekarskiemu dodatkowego urlopu.

W dalszym ciagu ks. Anders swoją działalność pastoralną w Piekarach przedzielał kuracjami w Kudowie lub w Domu „Caritasu” we Wrocławiu. Mimo to stan jego zdrowia ciagle ulegał pogorszeniu. Świadczy o tym jego obszerna korespondencja $z$ Wikariatem Generalnym. Zwykle po odbytej i przedłużonej kuracji powracal do aktywnej działalności duszpasterskiej. I tak np. z okazji setnej rocznicy śmierci T. Kościuszki w dn. 15 X 1917 r. proboszcz wygłosil patriotyczne kazanie, a prasa odnotowała fakt śpiewu „pierwszy raz od niepamiętnych czasów” pieśni „Boże coś Polskę”. Wtedy też zezwolił na kwestę przed kościołem „na głodujacych Polaków z Kongresówki".

Po 11 XI 1918 r., gdy na froncie zachodnim podpisano zawieszenie broni i zakończyły się działania I wojny światowej, a do domów nie wróciło ponad stu

${ }^{69}$ Modlitewnik ten, pt. Przewodnia ksiązeczka nowej Kalwaryi w Piekarach. Na większa chwałe Bogu i cześć Najświętszej Panny Maryi ku pożytkowi wiernych, został wydrukowany przez lokalne czasopismo S. Czerniejewskiego „Gwiazda Piekarska”. Zawierał 256 stron dużego i wyraźnego druku. Na stronie przedtytułowej zamieszczono fotografię zmarłego w roku 1895 ks. L. Nerlicha oraz wielką fotografię nowo wybudowanej kalwarii na wzgórzu Cerekwica.

${ }^{70} \mathrm{Ks}$. Anders zamieścił w kalwaryjce także 4 fotografie: cudownego obrazu Matki Bożej, kościoła pielgrzymkowego pw. Imienia Najświętszej Maryi Panny, fundatora kalwarii ks. L. Nerlicha i ogólny widok alwarii. Mimo dodatku objętość modlitewnika ks. Andersa była mniejsza o 70 stron.

71 „Dziennik Śląski” 1917 nr 152.

72 „Katolik" 1917 nr 87. 
mieszkańców Piekar, poczuwał się zobligowany do urządzenia nabożeństwa za tych, którzy pojedynczo lub gromadkami wracali z różnych frontów.

Dnia 28 stycznia 1919 r. celebrował Mszę św. do Matki Boskiej Częstochowskiej[!] o uproszenie darów Ducha Świętego đla konferencji pokojowej w Paryżu, by „wszelkie rzeczy tam sprawiedliwie załatwiono" "73. Zachęcał wiernych do składania datków na tzw. podatek narodowy ${ }^{74}$. Czasem brał udział w obchodach kalwaryjskich; odpustów starał sie nie opuszczac ${ }^{75}$, wszak zwykle brało w nich udzial okolo 50-70 tys. wiernych ${ }^{76}$, a w ciagu dnia celebrowano aż 24 Msze św. Na początku czerwca 1919 r. udało mu się zakończyć sprawę kupna 5 mórg terenu na powiększenie cmentarza ${ }^{77}$. Potwierdza to osobna korespondencja ks. Andersa, proszącego kard. G. Koppa o pozwolenie na poświęcenie działki pod cmentarz z dn. $30 \mathrm{~V} 1919 \mathrm{r}^{78}$.

Po siedmiu latach policyjnego zakazu ( $\mathrm{z}$ powodu wojny) urządzania pielgrzymek do Częstochowy został współorganizatorem masowej polskiej pielgrzymki wiernych nie tylko $z$ Piekar, ale $z$ terenu całego Górnego Śląska ${ }^{79}$, która nie obyła się bez kłopotów natury politycznej ${ }^{80}$.

Gdy wybuchło I Powstanie Ślaskie 17 VIII 1919 r., ks. Anders już od pewnego czasu cierpiał na chorobę nerek. W niespokojnych wydarzeniach społeczno politycznych i narodowych na Górnym Śląsku, które także nie omijały Piekar, nie brał udziału. Choroba, podczas której nie opuszczał łóżka, trwała trzy miesiące. Wikariat Generalny we Wrocławiu odmówił mu dodatkowego dwumiesięcznego urlopu, o który prosił. Stanowisko to uzasadniono stwierdzeniem: „Piekary tak długo bez proboszcza zostać nie mogą". Proboszcz zatem lojalnie odniósł się do zalecenia władzy duchownej.

Od tej pory, co potwierdza analiza ksiag protokołów niektórych religijnych organizacji parafialnych w Piekarach, proboszcz nie w pełni panował nad życiem parafialnym. Nie potrafił np. zabezpieczyć ich normalnego funkcjonowania w okresie radykalizacji postaw narodowych parafian i patników, co wynikało z rozwoju sytuacji politycznej na Górnym Sląsku. Prezesi niektórych organizacji nie wywiązywali się z przyjętych na siebie obowiązków. Proboszcz nie potrafił wyegzekwować od nich realizacji obowiązków, ponieważ sam był chory. Niektórzy członkowie organizacji, świadomi rozluźnienia dyscypliny organizacyjnej, a nadto

73 „Dziennik Śląski $1916 \mathrm{nr} 152,158$.

74 "Dziennik Śląski" $1919 \mathrm{nr} 81$.

75 "Dziennik Ślasski" 1919 nr 91, 100, 179.

76 „Katolik” $1916 \mathrm{nr} 88,155,168$.

${ }^{77}$ Zabiegi o teren przyległy do cmentarza rozpoczął już w październiku 1918 r. Zob. korespodencja ks. Andersa do kard. G. Koppa z 24.10.1918 r. AAK, Acta Furstbischoefl. General-Vicariat - Amts zu Breslau betreffend: Eugen Anders, Rep. A-45, Vol 1, k. 90.

${ }^{78}$ Tamże.

79 „Dziennik Śląski” $1920 \mathrm{nr} 170,185$.

${ }^{80}$ Pielgrzymki Niemców z Piekar $\mathrm{j}$ okolicy (najczęściej do Warty) korzystały z usług niemieckiej policji bezpieczeństwa, zwanej przez Polaków „Sicherką”. Zob. „Dziennik Śląski” 1920 nr 185. 
widząc brak reakcji proboszcza na ten stan rzeczy, zaczęli wyrażać swoje oburzenie. Życie organizacyjne zatem jakby obumierało. Organizacje zaczęły także tracić oddanych dotąd czlonków. Sprzyjała temu sytuacja społecznopolityczna społeczeństwa polskiego na Górnym Śląsku.

Proboszcz piekarski nie potrafił także wpłynąc na rozbujały entuzjazm narodowy niektórych parafian $z$ kręgów powstańczych, działaczy narodowych i propolsko nastawionych wiernych, którzy z tego powodu zaznali w przeszłości i zaznawali obecnie wielu krzywd ze strony Niemców i ich sympatyków. Dotyczyło to szczególnie znienawidzonego Grenzschutzu. Wielu wiernych doznawało więc krzywdy. Świadczą o tym zapiski w Kronice miejskiej Piekar ${ }^{81}$.

Proboszcz nie mógł także wyegzekwować od wikarych dodatkowej pracy, ponieważ i tak wielokrotnie zastępowali go w kościele i kancelarii parafialnej. Rok 1921, w którym aż 85\% mieszkańców Piekar podczas plebiscytu opowiedziało się za Polską ${ }^{82}$, zdaje się stanowić początek postępującego schyłku religijnej działalności organizacyjnej w parafii. Nie był to jednak proces długotrwały ${ }^{83}$, ks. Anders bowiem wrócił do aktywnej pracy już pod koniec pierwszej połowy 1922 r. Okazją była uroczystość 25 . lecia jego święceń kapłańskich, tradycyjnie zakończona akademią ${ }^{84}$. W czerwcu 1922 r. urządził srebrny jubileusz poświęcenia kalwarii (21 VI 1896) ${ }^{85}$, kilka dni później (był to szósty dzień operacji przejmowania części Górnego Śląska) witał Wojsko Polskie z gen. Stanisławem Szeptyckim na czele, któremu pokazał zasoby skarbca sanktuarium, m.in. kielich mszalny - prawdopodobnie dar króla Jana III Sobieskiego i monstrancję z $1710 \mathrm{r}$. wykonaną przez złotnika z Nysy, Vogelhunda, na polecenie żony cesarza austriackiego Leopolda I Eleonory ${ }^{86}$. Podobnie jak ks. J. Ficek w roku 1846 r. wobec króla pruskiego Fryderyka Wilhelma IV, ks. Anders wygłosił porywające przemówienie, przypominające pobyt w piekarskiej świątyni króla polskiego Jana III Sobreskiego udającego się $\mathrm{z}$ wojskiem pod Wiedeń $\mathrm{w}$ celu ratowania chrześcijańskiej cywilizacji Europy, oraz ponowne wyznanie wiary przez elektora saskiego Augusta II Mocnego. To symboliczne powitanie w Piekarach dostojników państwowych zapoczątkowało serię odwiedzin sanktuarium (m.in. przez gen. Stanisława Hallera, marszałka Józefa Piłsudskiego), które wynikały nie tyle z motywacji religijnych, ile $z$ legitymizacji ideologicznej, tj. $z$ odwoływania się przez władzę do wartości i pryncypiów, które mają tworzyć akceptację systemu politycznego ${ }^{87}$. Między tymi wizytami a innymi, jak bp. Stanisława Zdzitowieckiego (29 VIII 1922), nowo mianowanego administratora Administracji Apostolskiej dla polskiej części Górnego Śląska ks. A. Hlonda (17 XII 1922), wysokich przełożo-

${ }^{81}$ Zapiski w niej zostaly doprowadzone do roku 1930 . Wynika z nich także, że ich autorem była osoba związana $z$ ruchem socjalistycznym, która świadomie ignorowała wkład lokalnego Kościoła w rozwój życia społecznego.

${ }^{82}$ „Dziennik Śląski” 1921, nr 76. Cytowany wyżej autor książi Himmel uber Grenzen, Alfred Seidel podaje inną cyfrę: $72 \%$ za Niemcami.

${ }^{83}$ „Dziennik Śląski” $1921 \mathrm{nr} 295$.

84 "Dziennik Śląski” $1922 \mathrm{nr} 148$.

85 "Dziennik Śląski” $1922 \mathrm{nr} 166$.

${ }^{86}$ E. S z ra m e k, Przyjęcie wojsk polskich w Piekarach dnia 26 czerwca 1922 r., [w:] Piekary. Pamiqtka koronacji cudownego obrazu..., s. 110-112.

${ }^{87}$ Zob. W. S o k ó 1, Legitymizacja systemów politycznych, Lublin 1997, s. 29. 
nych zakonnych, którzy zaczęli przybywać jako pielgrzymi od 4 II 1923 r., ks. Anders moblizował swoje zdrowie i siły do dalszej pracy.

Mimo kilku przesłanych do urzędów Administracji Apostolskiej w Katowicach zaświadczeń lekarskich o stanie zdrowia, które systematycznie ulegało pogorszeniu, 01 III 1923 r. ks. Anders został mianowany dziekanem nowo powstałego dekanatu piekarskiego ${ }^{88}$. Nominacja oznaczała poszerzenie zakresu jego obowiązków. Odtąd probostwo nie mogło pełnić funkcji miejsca „reperowania" zdrowia proboszcza.

Dnia 19 VI tr. do Piekar przybył z wizytą Prezydent RP S. Wojciechowski ${ }^{89}$ w towarzystwie najbardziej znanego dzialacza politycznego i narodowego na Górnym Śląsku, dyktatora III Powstania Śląskiego W. Korfantego i marszałka Sejmu Śląskiego z ramienia chadecji K. Wolnego, kilka dni poźniej goście z Rzymu, a $30 \mathrm{VI}$ - nuncjusz papieski w Polsce abp L. Lauri, po nim zaś generalny inspektor kopalń M. Wojciechowski i M. z Dalborów Pewińska. Lista gości sanktuarium i kalwarii oraz ks. Andersa była znacznie obszerniejsza ${ }^{90}$. Wszystkich znamienitszych gości proboszcz podejmowal na probostwie. Jego stan zdrowia ciągle się pogarszal $^{91}$. W zebraniach dziekanów w roku 1923 w Katowicach ks. E. Anders nie brał już udziału ${ }^{92}$.

W styczniu 1924 r., by ratować zdrowie, pojechał do znanego wówczas zakładu leczniczego w Branicach (Heil- und Pflegeanstalt Branitz), w dawnym powiecie glubczyckim, gdzie obowiązki lekarza naczelnego najdłużej w historii zakładu pełnił jego brat Oskar Anders ${ }^{93}$. Po konsultacji z lekarzami 9 I 1924 r. (inne źródła w marcu 1924) zrzekł się probostwa w Piekarach w piśmie z dn. 1 IV 1924 roku. Zmarł w mieszkaniu brata 7 XI 1924 r. $^{94}$

Ks. E. Anders nie tylko w Piekarach dal się poznać jako gorliwy duszpasterz, który dawal Chrystusowi dobre i ze wszech miar wiarygodne świadectwo prawi-

${ }^{88}$ Składał się on $\mathrm{z}$ następujacych parafii dotychczasowego archiprezbiteratu mysłowickiego: Huty Laury, Michałkowic, Siemianowic. Do nich „dołączono" Brzeziny Ślaskie, [Brzozowice] Kamień, Radzionków, Wielką Dąbrówkę i Piekary z dotychczasowego dekanatu piekarskiego. Zob. „Rozporządzenia Administracji Apostolskiej Śląska Polskiego”, Katowice 1923, s. 4, nr 21.

89 "Katolik Codzienny“ 1923 nr 145, 146.

90 "Zob. Fundations-Buch der neuen Marien-Kirche zu Deutsch-Piekar, in PreussischOber-Schlesien oder Namens Verzeichniss ihrer mildthaetigen Goenner im In und Auslande, unter den hohen Patronate des Koeniglichen Fiscus und dem besonderen Allerhoechsten Schutze seiner Majestaet der Preussen-Koenigs Friedrich Wilhelm des Vierten, Hoechst welcher in der Zahl der dieses Heilightum betretenden Monarchen der Erste ist, und zum Zeichen der Koeniglichen Huld allergnaedigst hier zu unter-zeichen geruhste, Arch. Paraf. Piekary, rkp., bez sygn.

91 „Dziennik Śląski” 1921 nr 295; 1924 nr 269.

92 Administrator Apostolski ks. dr. A. Hlond przystał na prośbę proboszcza piekarskiego i przysylał mu na piśmie treść uchwalonych rezolucji.

${ }_{93}$ A. J o n e c k o, L. Ko r c, Szpital Psychiatryczny w Branicach na Ślasku Opolskim jako dzieto biskupa Józefa Nathana, [w:] Biskupowi Józefowi Nathanowi w holdzie, red. J. Kopiec, Opole 1997, s. 72.

94 „Rozporządzenia Administracji Apostolskiej Śląska Polskiego”, Katowice 1924, s. 116, nr 363 . 
dłowo uformowanej tożsamości kapłańskiej ${ }^{95}$. Nieco słabiej na tym tle rysuje się działalność budziciela ludu śląskiego w sanktuarium mającym wielkie tradycje obrony ludu polskiego i jego praw, ale to przecież nie było jego zasadniczym zadaniem. $W$ parze $z$ pewną negacją tendencji germanofilskich ks. Andersa nie szła jego długotrwała praktyczna działalność w religijnych organizacjach parafialnych. Wynikało to głównie ze stanu „rozłamania zdrowotnego" ks. Andersa, który był dla niego czynnikiem mobilizującym do wytężonej pracy nad utrzymaniem powierzonej mu bazy materialnej a szczególnie kaplic kalwaryjskich na wzgórzu Cerekwica wraz z kościołem kalwaryjskim, w krótkich okresach zmniejszonych dolegliwości chorobowych. Jego „odchodzenie” tworzyło pasmo zmagań z dręczącymi go chorobami ${ }^{96}$. Ponieważ trwało długo, wierni w pewnej mierze przyzwyczaili się do jego licznych okresów leczenia i rekonwalescencji, a także do braku rezydencji w powierzonej mu parafii.

Ks. Anders nie należał do panteonu duchowieństwa gómośląskiego, w skład którego wchodzili tacy duchowni, jak ks. J. Ficek, ks. J. Szafranek, ks. A. Skowroński, ks. J. Kapica, ks. P. Brandys czy ks. E. Szramek, ale był pewnym symbolem walki $z$ chorobą i poświęcenia dla sprawy kapłaństwa. Był także jednym $z$ głównych świadków bogatej historii sanktuarium maryjnego w Piekarach koło Bytomia.

\author{
Eugenius Hugo Edward Anders (1874-1924) \\ praepositus et primus decanatus in Piekary decanus \\ Summarium
}

In numero multorum Silesiae Superioris meritorum sacerdotum Eugenius Anders habetur, qui Anno Domini 1913 praepositus sanctuarii Beatae Mariae Virginis in Piekary prope civitatem Bytom siti, nominatus est. Eo parocho vix undecim annos residente primum bellum mundanum gerebatur nec non multae controversiae litesque Polonorum et Germanorum in Silesiae Superioris sortibus ortae sunt. Hic rebus factum est, ut tres seditiones facerentur et pars harum terrarum Poloniae ingeretur. Dominus Anders quamvis morbis variis laborans inceptis negotiis praedecessorum suorum assiduam curam et operam dabat ac munera sacerdotalia summo studio adimplebat. Numerum celebrationum in sanctuario auxit, agmina peregrinatorum maiori semper in numero affluentium ordinavit, cantum ad Festum Nativitatis Christi, cum homines ad cantandum convenire solebant, fovit atque sustentavit. Anno 1917 librum novum, qui de calvaria inscribitur, in lucem edidit. Que omnia ah en facta oblivinni venisse videntur Inse enim tamquam sanctuarii administrator, qui magistratus ac publicos ministros hospitio excipere solebat, plerumque memoratur. Exemplum singulare adversus Ecclesiam pietatis ac in afflictionibus perseverantiae vir ille nobis praebuit, tamen nomen eius a scriptoribus, sive Polonis sive Germanis, vitam, mores et facta virirum illustrium exponentibus omittitur.

\footnotetext{
95 „Katolik Codzienny” 1924 nr 269.

96 „Dziennik Śląski” 1921 nr 295; 1922 nr 148.
} 